\title{
About Research in the Arts: a lover's discourse
}

\author{
Victoria Pérez Royo \\ Universidad de Zaragoza - Zaragoza, Spain
}

\begin{abstract}
About Research in the Arts: a lover's discourse - This paper is the result of an exercise of experimental re-writing and analogical thinking which had as an aim to open a new perspective on research in the arts. In terms of method, the different figures of love in Barthes' A Lover's Discourse are forced to talk about the relationship of researcher and object of study. This analogy allows us to find quality parameters based on a scale of values different to the hegemonic ones in the academy (productivity, competitiveness, innovation). These new parameters might constitute a solid ontological basis to build a new politics of artistic research in the academy that allow a radical reconsideration of processes of artistic research. Keywords: Artistic Research. Love. Analogy. Ethics of Research. Subjectivity.
\end{abstract}

RÉSUMÉ - De la Recherche en Arts: un discours amoureux - Ce texte découle d'un exercice de réécriture expérimentale et d'une pensée analogique visant à ouvrir une nouvelle perspective sur la recherche en arts. Sur le plan méthodologique, il s'agissait de faire dialoguer les différentes figures de l'amour dans l'ouvrage Fragments d'un discours amoureux, de Roland Barthes, au sujet de la relation entre chercheur et objet d'étude. Cette analogie nous permet de révéler des paramètres de qualité alternatifs aux échelles de valeurs actuellement hégémoniques au sein de l'université (productivité, compétitivité, innovation). Ces nouveaux paramètres pourraient constituer une base ontologique solide pour le développement d'une nouvelle politique de recherche artistique à l'université, nous permettant un réexamen radical des processus de recherche artistique.

Mots-clés: Recherche Artistique. Amour. Analogie. Éthique de la Recherche. Subjectivité.

RESUMO - Sobre a Pesquisa nas Artes: um discurso amoroso - Este artigo resulta de um exercício de reescrita experimental e de um pensamento analógico cujo objetivo era abrir uma nova perspectiva sobre pesquisa nas artes. Metodologicamente, as diferentes figuras de amor no livro Fragmentos de um Discurso Amoroso, de Barthes, são levadas a conversar sobre a relaçáo entre pesquisador e objeto de estudo. Essa analogia nos permite encontrar parâmetros de qualidade baseados em uma escala de valores diferentes dos hegemônicos na academia (produtividade, competitividade, inovação). Esses novos parâmetros podem constituir uma sólida base ontológica para a construção de uma nova política de pesquisa artística na academia que permita uma reconsideração radical dos processos de investigação em artes.

Palavras-chave: Pesquisa Artística. Amor. Analogia. Ética de Pesquisa. Subjetividade. 
The most fragile moment in artistic research is located at its birth, when as yet it doesn't even have a name, so as not to talk about potential visible and quantifiable results. This is the creative moment when the artist finds herself working with the research subject-matter without knowing yet exactly where it will lead to, or being able to imagine the ways in which she'll make her work public. This is a phase in the creative process that receives scant attention in discussions about research into the arts, and about research in broader terms (research into other fields of knowledge located within the academic field). Instead, discussions aimed at reforming, reorganizing and regulating research focus on assessing the results, both of production (can a doctoral thesis limit itself to a work of art or series of them; or should it, in addition, consist of a piece of writing that sets out a practice?; what should a paper written at the end of a master's course consist of?), and ones related to the researcher (what are the skills that a person ought to have acquired in order to obtain a master's degree?).

It's understandable not to want to get onto the thorny ground of the artist's subjectivity: working procedures are wholly personal and are very difficult to extrapolate to other cases; the mechanisms by which the imagination sets out to solve the problems raised by the research are hard to put one's finger on. So, the difficulty of organizing a universalizing system, or one with at least the bare minimum of general applicability, is enormous. Nevertheless, I think it's worth trying to address that complexity with a view to finding parameters to guide one towards research and creation programmes that will not simplify the research or reduce it to its results, but rather will pay special attention to the specific features of the creative moment at the moment of its birth, so that the conditions that will best promote it can be created. For this purpose it is essential to enter into the actual time when the creation is taking place and to pay attention to the phases the researcher goes through, along with the working processes and the emotions, moods and upheavals connected with them. I'm talking here not about introducing into programmes the figure of a psychologist who helps those students who have the biggest problems, but about studying that moment as a whole, without abstracting basic ingredients of the creative process such as emotions, so as to enable us to organize the times and places 
for creation, and the moments of solitude and of dialogue with others in relation to them. What I'm talking about is delving deep into the functioning of subjectivity in the work of research and creation, so that it gives us clues leading to one or other type of study programme in practical terms ${ }^{1}$.

I intend to address artistic subjectivity in the early moments of creation through an analogy with the figure of love. From this place, from the topos of love, it seems possible to access the task of subverting, dismantling, reconstructing and rethinking a structure that is at the basis of a historically very skewed concept: the relationships between the researching subject and the object of study; this is a relationship that, from my point of view, needs to be reformulated in order to be able to find novel and, above all, fair ways of approaching research processes $^{2}$. Accordingly, I intend to focus in this text on artistic subjectivity at research's moment of birth and on its relationship with the object of study by comparing it with a lover's relationship with his beloved. Since the object of study is regarded as an Other, the ethical question of research and creative work unfailingly raises its head; this is a subject that has been pushed aside for too long, relegated to the sphere of the private and individual, without a space of its own in which to be publicly discussed and be treated and recognized as a common and shared phenomenon ${ }^{3}$. If we look at the particular relationship that grows up between the researcher and the object of her research from the point of view of love, there come to light a series of moments, difficulties, stages in a common process, which it is worth paying attention to if we really want the arts to have that innovative position from which they can reform and reinvent research. From there it may be possible to design curricula that are not based on criteria such as productivity, competitiveness, innovation - which, to a great extent, are the bane of people like us who work in this sphere. Naturally, I'm not suggesting that we be sloppy about organizing curricula, but rather that we search for quality parameters based on a different scale of values, with an ethic and an educational policy that don't adopt external dictums, fed in from other disciplines and from the prevailing economic climate, but seek them instead in other places, starting with the closest and most private, viz. the researcher's relationship with the subject of her study.

What interests me about the analogy of the lovers is that it makes it possible to conceive of this bond as a give-and-take, in which 
both termini undergo a transformation ${ }^{4}$. The relationship is not a dispassionate one, but is swayed by feelings. This image leaves us room for thinking of the artist's subjectivity not as an all-powerful agency vis-à-vis an inert object, but rather in terms of being face-toface with an other that can no longer be cut down to size so as to reduce it to what we are accustomed to call an object of study.

In terms of methodology, I've decided to adopt a procedure tried out by Roland Barthes in Fragments d'un discours amoureux. In this text, the French author compiled fragments of literature in which the loved subject expresses herself directly. He organized these discourses into groups of figures, such as The Absent One (Barthes, 1977, p. 13), Catastrophe (Barthes, 1977, p. 48), I Want to Understand (Barthes, 1977, p. 59) named by him, that stand for various recognizable milestones present in most relationships - but nevertheless wholly personal - between lovers. Along with the name of the figure, Barthes includes a short text that contextualizes, details or glosses both the figure and the compiled texts. Barthes' intention in this book was essentially to give voice to a muted, hushed discourse, and to do so with no mediation. In my case, I've chosen to consider the fragments that Barthes compiles and the glosses that he includes with the aim of producing from them what he called a lecture, which necessarily generates another text, the present one. Starting out from his concept of the text as a production (open and giving rise to new creations) and not as a product (closed in upon itself and with no potential to live other lives, to attain and express other feelings), I propose to shift these figures and the texts that give them an image into a new context. Where research and creation are concerned, Barthes' discourse can go off the rails and cause these same words to speak analogously not of Werther's love for Charlotte, or Socrates' for Alcibiades, but of the relationships between researching artist and the subject-matter with which she works. To achieve this, alongside the name of the figure suggested by Barthes, I shall put a subtitle that transposes those words to the sphere of research; and I shall include with the fragments a series of paragraphs in which the figure is reinterpreted and the words are redirected from the practice of love to that of art. Finally, in some cases I shall include fragments of texts by other authors who have (effectively) studied research in its nascent state, that provide a clear parallel to what is suggested in each figure. 


\section{Affirmation - the intractable, or: the desire to research, beyond success or failure}

Affirmation. Against and in spite of everything, the subject affirms love as value. [...] The world subjects every enterprise to an alternative; that of success or failure, of victory or defeat. I protest by another logic: I am simultaneously and contradictorily happy and wretched; 'to succeed' or 'to fail' have for me only contingent, provisional meanings (which doesn't keep my sufferings and my desires from being violent) (Barthes, 1977, p. 22).

The practice of researching and the time invested in dealing with the subject-matter worked with, are affirmed as values in themselves, beyond their potential success (such as obtaining as a result of the research a piece that functions) or their potential failure (I can't manage to conclude the research with a visible or presentable result from which the work I put in can at least be appreciated). Indeed, what is affirmed as a value is the desire to work with those materials, to apply oneself to them without trying to guess at the outset what the effort might yield. This does not in the least imply an indulgent view of the materials and of the research activity itself, but instead, different work-economics: rather than the result being regarded as a parameter for setting values, the judging of the process itself is much stricter, in so far as it is determined according to the researcher's level of dedication; the extent to which she gives it her full and heartfelt attention; her skill at generating a relationship with the subject-matter; and the quality of the dialogue set up. These parameters are wholly subjective, and very often the person best qualified to judge the real validity of the research is the person who carried it out - in so far as she knows the process perfectly, along with the extent of the transformation that both object and subject have undergone in that process.

Flouted in my enterprise (as it happens), I emerge from it neither victor nor vanquished: I am tragic. (Someone tells me: this kind of love is not viable. But how can you evaluate viability? Why is the viable a Good Thing? Why is it better to last than to burn? (Barthes, 1977, p. 23).

In these economics, which do not involve a guess as to the viability or otherwise of arriving at a shareable end result, the artist's desire to work with the object is affirmed. It is precisely this endeavour that eventually leads the research to bear its genuine fruits: 
to arrive at the unexpected, the unforeseeable; to make a qualitative leap in knowledge. What one sets out to know and has hypothesized with varying degrees of certainty from the outset turns out to be less valuable than the unforeseeable experience or knowledge that arises without having been aspired to beforehand.

\section{The Catastrophe, or: radical questioning of the value of the research (and an opportunity to strip it down to the basics)}

Catastrophe. Violent crisis during which the subject, experiencing the amorous situation as a definitive impasse, a trap from which he can never escape, sees himself doomed to total destruction (Barthes, 1977, p. 48).

The catastrophe is the tragic moment in the research: the artist ${ }^{5}$ finds herself in a bottleneck, thinks all the work she's put in has been in vain; that she hasn't found any worthwhile leads or that the ones she's found are futile or have been followed already. It's a moment when there are no more words that can be spoken to the object of the research; when the researcher doesn't know how to question the object, or when she feels that whatever she might say lacks value; she has the idea of giving up and starting over again with a new project.

Instead of regarding the catastrophe as a moment of crisis in the process of research and creation - one that the person must avoid at all costs, and make sure it doesn't happen again - it's worthwhile understanding it, from the amorous point of view, as a necessary phase that arises sooner or later in every creative process, wherein the research comes under questioning down to its very foundations; wherein the value of all the activities carried out up to that moment is re-examined. So, the catastrophe is understood as an opportunity, since it gets the researcher to do the very necessary job of dispensing with many of the lines of research that she had open and many of the materials on which she had been working and which are perceived, following the purification that the catastrophe brings about, as nonessential or as clutter.

This approach is advantageous in study programmes, since it brings about a different understanding of the processes of research and creation. Instead of looking upon it as a problem particular to certain students who perhaps are labelled inefficient or unskilled at salvaging the materials they have worked on, one understands it as a 
phase in the process that inevitably takes place in all research projects. In view of its potential, it seems a good idea to take advantage of it for organizing the activities of the programme: to allocate a time which each person will organize individually - during which she will require more time alone in order to step back from the problem and look at it from farther away; a confidant (tutor) who will help the student to map out the research done up to that moment; and work-showing sessions, during which the group will contribute to selecting the materials that they will carry on with.

\section{Want to Understand, or: reflection and reflexiveness in research}

To understand. Suddenly perceiving the amorous episode as a knot of inexplicable reasons and impaired solutions, the subject exclaims: 'I want to understand (what is happening to me)!' (Barthes, 1977, p. 59).

The excerpt brackets "(what is happening to me)" in this text by Barthes is fundamental. A research project doesn't consist solely of extracting knowledge of the object as an entity separate from the subject analysing it, but also (or perhaps principally) of knowing how the subject is affected by that interaction and how she defines herself in relation to it. In contrast to the customary way of understanding research (as a stable subject who analyses an object with a prior identity in order to extract knowledge of it), with this figure a different distribution is drawn: research consists first and foremost of an encounter in which two entities define themselves reciprocally in their interrelationship. When it comes down to it, it's a case of knowing the way one acts; being aware of one's own way of formulating problems and getting to grips with them.

For this purpose one needs to get on the move; to cease to be bound up with the object; to come out of one's own methods of communicating created together with it and to shift into a different language; to step back from oneself; to formulate oneself in different materials - since the intensity that characterizes creation in its first moments doesn't allow that stepping back, and consequently it gets in the way of reflectiveness:

What do I think of love? - As a matter of fact, I think nothing at all of love. I'd be glad to know what it is, but being inside, I see it in existence, not in essence. What I want to know 
(love) is the very substance I employ in order to speak (the lover's discourse). Reflection is certainly permitted, but since this reflection is immediately absorbed in the mulling over of images, it never turns into reflexivity: excluded from logic (which supposes languages exterior to each other), I cannot claim to think properly. Hence, discourse on love though I may for years at a time, I cannot hope to seize the concept of it except 'by the tail': by flashes, formulas, surprises of expression, scattered through the great stream of the Imagerepertoire; I am in love's wrong place, which is its dazzling place (Barthes, 1977, p. 59).

Within one's own materials and the new ones that are generated over the course of the research project there is thought and reflection; but it's an inherent kind of reflection, one that dwells within the materials (see Signs) and in the very body of the researcher - one that is expressed in its particular and specific form. They are written in that unique language that has been developed jointly with the object of study, and which could be labelled with the oxymoron private language. In order to step back and allow reflexivity to take place, it's important in artistic research to switch between several modes of working: one that comes from the materials, another one that's on them - expressing the relationship between subject and object in several languages, articulating it and sharing it with others. It's the difference, already formulated, between search and research, wherein that prefix re causes the stepping back, that enables the researcher to attain a reflexive dimension to her own action and her own subjectivity. The moment of euphoria when dealing with the materials isn't the best one for understanding our own action, because we're dazzled by them; however, this understanding can be achieved in a subsequent reflexive moment, when we step back from them and from our own activity through communication: "My body became at the same time active and productive, object and subject, analyser and analysed, product and producer" (Le Roy, 1999, n.p.).

\section{Connivance, or: communication needs over the course of the research project}

The person with whom I can in fact talk about the loved being is the person who loves that being as much as I do, the way I do: my symmetric partner, my rival, my competitor. [...] I can then, for once, discuss the other with someone who knows; there occurs an equality of knowledge, a 
delight of inclusion; in such discussion, the object is neither distanced nor lacerated; it remains interior to and protected by the dual discourse (Barthes, 1977, p. 65).

In many cases, it's not the figure of the tutor, of an artist or an academic, with a lot more experience, savoir faire and knowledge behind her, who is the person best equipped to help with a research process in an academic context of postgraduate studies. Through their experience, these people can provide reassurance that there's a way out of the dead ends that the research has reached (the Catastrophe figure). But in other cases a lot more benefit can be obtained from discussion between peers: we at the Master's Programme in Performing Arts Practice and Visual Culture (MPECV) call this collective mentoring, whereby the group of students help one another to formulate and solve problems over the course of the research project. They aren't regarded as peers in the sense that they share the same object of research; however, they do share the same way of being immersed in their research, and the same position from which to create a common language that can't be created with the mentor due to the greater distance involved.

\section{Contacts - when my finger accidentally..., or: the ways of thinking inherent in artistic practice}

Contacts. The figure refers to any interior discourse provoked by a furtive contact with the body (and more precisely the skin) of the desired being. [...] This trivial gesture, which I begin, is continued by another part of myself; without anything interrupting it physically, it branches off, shifts from a simple function to a dazzling meaning, that of the demand for love. Meaning (destiny) electrifies my hand; I am about to tear open the other's opaque body, oblige the other (whether there is a response, a withdrawal, or mere acceptance) to enter into the interplay of meaning: I am about to make the other speak (Barthes, 1977, p. 68).

I am especially interested in the moment when the researcher and the object of her research come into contact, following prior observation from a distance. That contact unquestionably indicates a desire to get into the object of study; to research its mechanisms, its functioning, and to strike up an intimate relationship with them that causes them both to be transformed. I'm interested because when the contact takes place - when the researcher finally gets working 
directly with the materials - an especially interesting way of thinking emerges: an embodied one; one that is inherent in and intrinsic to the materials and which, in that start-up phase of the research project, is inseparable from them.

This figure, the contact, signals the moment when the researcher sets to work and engages fully with the materials: delves into them, pulls them apart, decontextualizes them and rebuilds them using a different logic. She appropriates the materials, messing with them and plunging her hands into them. So, this pulling the Other's body apart expresses that particular type of artistic thinking: not abstracted from the object, but rather incorporated into it; inherent in the materials and inseparable from them. Its particular, specific and concrete nature is precisely what triggers a type of thinking that, rather than occurring in a second instance (see the figure Understanding), expressed or articulated in different language, does so directly within and from the materials being handled, within and from the own body. It's worth drawing attention to this type of thinking because artistic research usually prefers to associate with the moment of reflexivity when an evaluation of the researcher's own activity is made, and tends to overlook this other way of thinking which is inherent in the object and is of fundamental importance in the emerging phases of the research project.

The odd notion that an artist does not think and a scientific inquirer does nothing else is the result of converting a difference of tempo and emphasis into a difference in kind. The thinker has his aesthetic moment when his ideas cease to be mere ideas and become corporate meanings of objects. The artist has his problems and thinks as he works. But his thought is more immediately embodied in the object. Because of the comparative remoteness of his end, the scientific worker operates with symbols, words and mathematical signs. The artist does his thinking in the very qualitative media he works in, and the terms lie so close to the object he is producing that they merge directly into it (Dewey, 1934, p. 15-16).

\section{Errantry - the ghost ship, or: research above and beyond the concrete products that it generates}

Though each love is experienced as unique and though the subject rejects the notion of repeating it elsewhere later on, he sometimes discovers in himself a kind of diffusion of 
amorous desire; he then realizes he is doomed to wander until he dies, from love to love (Barthes, 1977, p. 101).

Research doesn't end with the production of a work. The piece is a prime moment in the sharing of the research project, but it isn't its ultimate goal or sole aim. There are many ways of making a research project known, such as tools, talks and process-showings; the work of art is one of them. So, the research project doesn't stop there: instead, the researching subject finds that some initial questions lead to others, whereby over the course of her life she creates research in a continuous stream, passing from one object of study to another; from formulating a problem to rearticulating it, and finally transforming it into something new and oneself being transformed anew. Over the course of the research there are certain turning points, the artistic works, which mark the places where the researcher has shifted from one set of fascinations and crazes to another.

\section{Waiting, or: daily life placed at the service of the object of research}

Tumult of anxiety provoked by waiting for the loved being, subject to trivial delays (rendezvous, letters, telephone calls, returns). [...] In the cafe, anyone who comes in, bearing the faintest resemblance, is thereupon, in a first impulse, recognized (Barthes, 1977, p. 37-39).

For the duration of the researcher's obsession with a theme or a set of materials, over the time of the research project, the object is capable of colouring all the world's other contents, causing reality to be interpreted by reference to itself. New insights into how to handle it, ideas for making headway with the research project, are never sure fire formulae that will guarantee us plain sailing; rather, they emerge as flashes of inspiration that will light the way ahead for us. So, content that shows up in the researcher's non-research, personal life (films, anecdotes, reading-matter, conversations) is viewed in terms of its resemblance to the object of study; the extent to which it helps her discern and understand it. Although the type of perception is constant, the flashes of inspiration come at the oddest moments, when the researcher isn't consciously applying herself to solving the problems.

Incubation [within the research process] is a sort of mobilization of mental and natural resources; it's a 
distortion of the world for the benefit of the set problem: the discoverer deforms the world, things and beings to the advantage of himself alone, and cannot (to some degree or other) see in external phenomena, anything other than that which links them, either mediately or immediately, in some way with the diffuse object of his interest (Moles, 1957, p. 257).

\title{
Expenditure - exuberance, or: the transgressive power of research lies in its being an end in itself, rather than a means to an end
}

\begin{abstract}
A figure by which the amorous subject both seeks and hesitates to place love in an economy of 'total loss'. [...] Love-as-passion is therefore a force, a strength ('this violence, this stubborn, indomitable passion'), something which suggests the old notion of $1 \sigma \chi v \xi$ (ischus: energy, tension, strength of character), and, closer to us, that of Expenditure (Barthes, 1977, p. 84).
\end{abstract}

Over the course of a research process one generates an excessive "expenditure" of methods and working tools, procedures and ways of doing things - some of which are useless, some are forgotten as the process goes on, and a mere handful succeed in keeping alive the relationship between researcher and materials. What the researcher does is invent a multiplicity of methods and techniques for getting the materials to speak and respond to her. Although it is true that each of these invented strategies may have a specific purpose, the figure of Expenditure drives home to us that this goal is not external or foreign to the object of study; in point of fact, it is geared to intensifying the reciprocity between researching subject and object of study.

The lover's discourse is not lacking in calculations: I rationalize, I reason, sometimes I count, either to obtain certain satisfactions, to avoid certain injuries, or to represent inwardly to the other, in a wayward impulse, the wealth of ingenuity I lavish for nothing in his favor (to yield, to conceal, not to hurt, to divert, to convince, etc.). But these calculations are merely impatiences: no thought of a final gain: Expenditure is open, to infinity, strength drifts, without a goal (the loved object is not a goal: the loved object is an object-as-thing, not an object-as-term) (Barthes, 1977, p. 85).

There are calculations, strategies and knowings, which lead that dialogue on, to keep the researcher in that relationship with the materials and not exhaust it, in order to make the most of it and 
create an intense experience with them. But one can't speak of a final goal that lies beyond the materials, that is ontologically superior or is perceived as such. As far as the relationship with the materials goes, these are an end in themselves: the end is to deal with the problems that they bring up, to get to know them and oneself in the process; there is no other, more highly prized, goal beyond the object and the relationship with it that transforms both object and subject. Dealing with it generates knowledge; but this knowing isn't the ultimate goal whereby the materials are merely a means to an end: they are at once the medium and means of the relationship, and its final destination. This is a similar mechanism to the one identified by Lévi-Strauss for the savage mind:

[The savage mind] is neither the mind of savages nor that of primitive or archaic humanity, but rather mind in its untamed state as distinct from mind cultivated or domesticated for the purpose of yielding a return (LéviStrauss, 2009, p. 317).

\section{Gossip, or: the difficulty of dealing with the singular nature of artistic research}

Gossip reduces the other to he/she, and this reduction is intolerable to me. For me the other is neither he nor she; the other has only a name of his own, and her own name. The third-person pronoun is a wicked pronoun: it is the pronoun of the non-person, it absents, it annuls. When I realize that common discourse takes possession of my other and restores that other to me in the bloodless form of a universal substitute, applied to all the things which are not here, it is as if I saw my other dead, reduced, shelved in an urn upon the wall of the great mausoleum of language (Barthes, 1977, p. 185).

The object of study is totally singular - so much so that the researcher, in order to handle it, has had to invent a new language, a new way of doing things and a new procedure (or has had to reformulate and rearticulate those that she knew and used before). And this singularity extends to people who take an interest in the research project, such as tutors and lecturers. So, in some cases, classifying the object of study, assigning to it a pre-existing label, is tantamount to obliterating the researcher's desire, since it prevents her from recognizing the real object in the label placed on it. This doesn't mean it's not possible to relate it to other research projects, 
to similar cases; to offer criteria of intelligibility by comparing it to other cases - this can sometimes help propel the research forward; but when offering other materials that may help the researcher to picture the object of study more clearly, one must take care not to hedge it in with a limiting label along with other works or with a pre-formulated, stereotyped definition, since to do so is tantamount to freezing up its development.

Here again, we need to tread carefully: artistic research has its moment of openness, when the artist's own research and the knowledge gained can be shared; but sometimes it's difficult to discuss the progress of the research project without annihilating its power, the artist's desire to carry on handling the materials and posing questions to them. Those who offer support from the outside are on rocky ground, attempting to contextualize the object of study for the artist's benefit while respecting its unique nature.

\section{The Unknowable, or: the importance of recognizing the object of study's inexhaustible nature}

I am caught in this contradiction: on the one hand, I believe I know the other better than anyone and triumphantly assert my knowledge to the other (" know you-I'm the only one who really knows you!'); and on the other hand, I am often struck by the obvious fact that the other is impenetrable, intractable, not to be found; I cannot open up the other, trace back the other's origins, solve the riddle. Where does the other come from? Who is the other? I wear myself out, I shall never know (Barthes, 1977, p. 138).

One of the paradoxes of the research process is the object of study's inexhaustible nature: although one's dwelt a long time on it, although its mechanisms and behaviour have been thoroughly studied, there comes a moment of realization that one's explorations have covered just one, or a few, of the many aspects through which the object of study unfolds itself. There are two dimensions to this realization: one of them positive, in so far as it broadens and enriches the angles of study, thereby helping to propel the process forward; and the other negative: the realization that the object of study is unknowable may paralyze the research by bringing it home to the artist that she would have to go a very long way to be able to capture the object of study from a wide enough angle. This can make the 
start-up phase of the research project very long-drawn-out, since the creator (having discovered that everything she knows about the object is actually very little) feels she needs to gain a greater knowledge of the materials she's working with before making them public and sharing them. Every research process takes its time, and this fact must be respected (see Catastrophe); but what this figure emphasizes is the attention the artist must devote to a phase in the research project when she must momentarily shelve the object's other dimensions and focus solely on sharing it with the research community. If this moment is put off for too long, that private language can become over-worked to the point of becoming abstruse, and can thereby jeopardize the sharing of the research by making it a mammoth task.

Beyond the attempt to encompass the object of study in its entirety, inexhaustibility also relates to something else: it's unusual for a researcher to persevere until all the enigmas of the object of study have been solved; it is natural for her attention to shift (see the figure Errantry) to other problems that appeal through their novelty, or for the questions to be reformulated over time, leading the research path in new directions.

\section{Induction - show me whom to desire, or: the doses in which the student receives information}

The loved being is desired because another or others have shown the subject that such a being is desirable: however particular, amorous desire is discovered by induction. [...] The body which will be loved is in advance selected and manipulated by the lens, subjected to a kind of zoom effect which magnifies it, brings it closer, and leads the subject to press his nose to the glass. [...] This 'affective contagion,' this induction, proceeds from others, from the language, from books, from friends: no love is original. [...] The difficulty of the amorous project is in this: 'Just show me whom to desire, but then get out of the way!' Countless episodes in which I fall in love with someone loved by my best friend: every rival has first been a master, a guide, a barker, a mediator (Barthes, 1977, p. 136-137).

The first case that Barthes presents of falling in love by induction is that of Werther, who takes to Charlotte after overhearing a maidservant's comment: this anecdote shows that love is learned. Applying this to artistic research on educational programmes may 
lead us to think of the lecturer as an essential figure, since it is her enthusiasm for the object of study that may infect the researcher. But it's important to note that Barthes goes on to emphasize that induction doesn't occur just because someone shows the future object of love in a particularly interesting light; rather, the agents who facilitate that discovery, those that awaken the desire are also language, books, and a series of other agents. There are a whole series of "intercessors", as Deleuze suggests, who "[...] can be people - for a philosopher, artists or scientists; for a scientist, philosophers or artists - but things too, even plants or animals, as in Castañeda. Whether they're real or imaginary, animate or inanimate" (Deleuze, 1990, p. 125).

From this we gather that those catalysts that cause one to focus on a specific object (and consequently forget the rest) are not, in the context of a study programme, solely the lecturers or tutors, but all the materials (documents, texts, artistic works) that a student comes into contact with. I may be stating the obvious, but one needs to think of it from several points of view: from that of the subject studied, a balance between the information offered on a programme and the time that must be left for independent study; from the viewpoint of the importance of facilitating students' search for materials and handling of them rather than conveying knowledge. And, lastly, in respect of the final exclamation of the Barthes quote "Just show me whom to desire, but then get out of the way!" (1977, p, 137), the cultivation of a style of lecturing that encourages personal questioning and curiosity and that seeks a balance between the feeding of new information that students may find fascinating and the time needed for each one to handle it personally, independently, and adapt it to their own interests.

\section{The Informer, or: the tutor's delicate role}

A friendly figure whose constant role, however, seems to be to wound the amorous subject by 'innocently' furnishing commonplace information about the loved being, though the effect of this information is to disturb the subject's image of that being. [...] He reduces my other to being merely another. [...] By furnishing me insignificant information about the one I love, the Informer discovers a secret for me. This secret is not a deep one, but comes from outside: 
it is the other's 'outside' which was hidden from me. The curtain rises the wrong way round - not on an intimate stage, but on the crowded theater. Whatever it tells me, the information is painful: a dull, ungrateful fragment of reality lands on me. For the lover's delicacy, every fact has something aggressive about it: a bit of 'science,' however commonplace, invades the Image-repertoire (Barthes, 1977, p. 138-139).

The informer in Barthes' text denotes the figure of a friend who knows the loved person and who offers the lover public information about her. Since the loving person's exclusivist passion wants to imagine a world with just the two of us, this information is painful.

In the context of research and creation programmes, the equivalent figure to the informer may be that of the tutor or the person who supports a research process or follows it closely, since in many cases she functions as a bridge between the individuality of the relationship between the researcher/object of research pair and the research community. She is required to perform a difficult balancing act between the act of sparking the imagination that will reinvent the object and helping place that totally individual research on common ground that can be shared by other researchers in the same field of study. In other words, the tutor's delicate task is to consider the potential repercussions of the research once placed in the public domain while simultaneously respecting the imaginative quality of the individual, private and specific handling of the materials; and in doing so she must avoid the pitfall of using theories and universalizing explanations that will elicit only a weak response from the researching imagination or that will undermine the researcher's confidence in her personal handling of the materials.

The processes of incubation and insight [...] are followed by the process of verification, of which we must now hold onto a new dimension: the return to being in contact with the outside world [...] This stage of return to the concrete is essential and distinguishes creation from schizophrenia. [...] This socialization consists of getting the created object through a social barrier by bringing it out of the ivory tower where the creator is and placing it in the public domain (Moles 1957, p. 303-304).

Silence. No answer, or: the resilience that the object must have so that the researcher can readjust and reinvent her tools:

The amorous subject suffers anxiety because the loved object replies scantily or not at all to his language (discourse 
or letters). 'When you were talking to him, discussing any subject at all, $\mathrm{X}$ frequently seemed to be looking away, listening to something else: you broke off, discouraged; after a long silence, X would say: 'Go on, I'm listening to you'; then you resumed as best you could the thread of a story in which you no longer believed' (Barthes, 1977, p. 167).

Occasionally the object of study doesn't answer; it remains inscrutable and inaccessible to the researcher's hypotheses and questions. This leads the researcher to think that perhaps she hasn't asked it the right questions; perhaps she's used a language that the object doesn't speak, doesn't respond to - one that perhaps stems from a method applied to an earlier work. Or perhaps the questions that are posed to it are actually geared to other types of materials. But this silence, which in principle could be regarded as negative within the process of creation, potentially benefits the research from several points of view: firstly, as a symptom of the inadequacy of the researcher's communication with the object; in this case the silence will prompt the researcher to focus again on her tools, on the constructed language, on her own methodology, and to consider what she must do so as to move forward with the research. Secondly, the silence signals first and foremost this resilience's function as a driver of the research project's development. It continues for as long as there is a set problem to solve. Once the problems that were set have been explained, the questions that enliven the dialogue run out. The research project needs resilience that will provoke thought, attention and action. Lastly, it signals the unencompassable (because neverending) process of knowledge: each time the research broadens out and a new dimension of the object of study opens up, the researcher realizes that what she doesn't know is so much greater than what she knows; that any object of study is, merely by virtue of being such, unencompassable, unknowable in its entirety.

The existence of resistance defines the place of intelligence in the production of an object of fine art. The difficulties to be overcome in bringing about the proper reciprocal adaption of parts constitute what in intellectual work are problems. As in activity dealing with predominatingly intellectual matters, the material that constitutes a problem has to be converted into a means for its solution. It cannot be sidestepped (Dewey, 1934, p. 138). 


\title{
Ravishment, or: the destabilization of the positions of subject and object
}

\begin{abstract}
Ravishment. The supposedly initial episode (though it may be reconstructed after the fact) during which the amorous subject is 'ravished' (captured and enchanted) by the image of the loved object (popular name: love at first sight; scholarly name: enamoration). [...] In the ancient myth, the ravisher is active, he wants to seize his prey, he is the subject of the rape (of which the object is a Woman, as we know, invariably passive); in the modern myth (that of love-as-passion), the contrary is the case: the ravisher wants nothing, does nothing; he is motionless (as any image), and it is the ravished object who is the real subject of the rape; the object of capture becomes the subject of love; and the subject of the conquest moves into the class of loved object (Barthes, 1977, p. 188).
\end{abstract}

The figure of ravishment signals that what is usually termed the choice of a theme, the demarcation of a field of study, by the researcher, has a hidden side to it: it's not a case of a subject who decides voluntarily and through her sovereign choice to study this or that, but rather of someone in the grip of a fascination capable of reversing the roles conventionally assigned to a research activity: the object of study at that moment takes on the characteristic traits of a subject, in so far as it wields an influence over the researcher, subjugates her in such a way that the real agent who starts up actions is it, through the researcher, rather than the latter autonomously. The artist's decisions are nothing but answers to the necessities of the object of study. Thereby the very materials of the research project transform the notions inherited as authorship, signposting an escape route that leads away from the poetic notions of I express and towards the operations that the object of study suggests, indicates or even compels the researcher to carry out; this same gesture also entails a destabilization of the notion of author and style, in so far as the centre of action shifts from subject to object.

Moreover, this figure makes us mindful that research is not a means to an end (extracting a piece of knowledge) whereby the researcher tramples on the object or skips over it in order to obtain it. On the contrary: it is the object itself (the theme that has been found, the situation that fascinates, the field to be explored) and the relationship that is formed with it, that is the purpose of the research project. The pleasure of study lies in the encounter with the object and not in a goal hierarchically superior to it. 


\title{
Reverberation, or: reciprocity between subject and object within the research project
}

\begin{abstract}
What echoes in me is what I learn with my body: something sharp and tenuous suddenly wakens this body, which, meanwhile, had languished in the rational knowledge of a general situation: the word, the image, the thought function like a whiplash. My inward body begins vibrating as though shaken by trumpets answering each other, drowning each other out: the incitation leaves its trace, the trace widens and everything is (more or less rapidly) ravaged (Barthes, 1977, p. 200).
\end{abstract}

One can speak of a real dialogue between researching subject and object of study - one that fosters knowledge which not only affects the intellectual plane, but also has transformational abilities that are felt and suffered physically. This creates a relationship that is not unidirectional, in which the materials too are able to affect the subject; not just because, in a way, they offer answers to the questions she asks but, above all, because the researcher does not view these answers as data removed from life itself, but rather, she takes them physically into her body; their impact is not merely discursive, but also affective, emotional and sensitive. From this point of view, it's difficult to separate the research project from what is commonly called personal or private life: the subjectivity is transformed in a real way by what it knows.

And this transformation is fundamentally important, not just from the viewpoint of personal growth, but also because it fosters a more intensive type of research which recognizes that there are more dimensions to scientific activity than the traditionally accepted ones:

One does not evolve a sound science by ignoring its most basic and most characteristic data which are, quite specifically, the distinctive difficulties of that science. The behavioural scientist cannot ignore the interaction between subject and observer in the hope that, if he but pretends long enough that it does not exist, it will just quietly go away (Devereux, 1967, p. XVIII).

So, the effects that research has on the person who researches foster not only a reconsideration of the relationships between subject and object, but also a series of data and pieces of information of great value: not only the ones provided by the concentrated attention on the object of study, but also those that this observation and this relating produce on the researcher herself. 
The reintroduction of the observer, as he really is, into the experimental situation [is regarded] not as a source of regrettable disruption, but as an important and even indispensible, source of relevant, supplementary behavioural science data. This permits the exploitation of the sui generis effects of observation upon both on observer and observed, which are viewed here as key data (Devereux, 1967, p. 30).

\section{Signs - the uncertainty of signs, or: artistic research as a science of the concrete}

Whether he seeks to prove his love, or to discover if the other loves him, the amorous subject has no system of sure signs at his disposal. [...] A man who wants the truth is never answered save in strong, highly colored images, which nonetheless turn ambiguous, indecisive, once he tries to transform them into signs: as in any manticism, the consulting lover must make his own truth (Barthes, 1977, p. 214-215).

Communication with the object of study is not based on conventions or preset ways of working. One must start from scratch by inventing the private language that is going to be built up in the dialogue with them. There is no created system of signs that can be applied smoothly, without hitches; or, if a pre-created language is used, it refuses to work as one would hope: one will have to reinvent its grammar, its way of signifying; adapt it to the particular and specific features of the object of research.

The object of study and its specific nature, its connection with the researcher's concrete life, does not allow it to be subjected to a pre-created language that will explain it with total clarity; artistic research is a "science of the concrete" (Lévi-Strauss), wherein it is the object's specific qualities that give sense and substance to the research project; wherein the insignificant, the ways that the features show up rather than their essences, the details that, in principle, reason could disregard and the relationships that are formed between them, are the keys for constructing a meaning and trying to create a new language in order to communicate with it.

[T] he idea that the artist does not think as intently and penetratingly as a scientific inquirer is absurd. [...] To think effectively in terms of relations of qualities is as severe a demand upon thought as to think in terms of symbols, verbal and mathematical. Indeed, since words are easily 
manipulated in mechanical ways, the production of a work of genuine art probably demands more intelligence than does most of the so-called thinking that goes on among those who pride themselves on being 'intellectuals' (Dewey, 1934, p. 45-46).

\section{I-Love-You, or: research as an active and mindful exchange with the world}

[...] a new view of I-love-you. Not as a symptom but as an action. I speak so that you may answer [...] Hence it is not enough that the other should answer me with a mere signified, however positive ("So do I"): the addressed subject must take the responsibility of formulating, of proffering the I-love-you which I extend. [...] I-love-you is active. It affirms itself as force-against other forces. Which ones? The thousand forces of the world, which are, all of them, disparaging forces (science, doxa, reality, reason, etc.) (Barthes, 1977, p. 152-153).

When the researcher has found that theme, that situation, that which she wants to connect with, she approaches it; she speaks to it. This is no pointless monologue: she asks it questions because she really does expect an answer, in spite of all that common sense might suggest to the contrary. Rather than manipulating it, she poses questions in the hope of eliciting an answer. The object, for its part, is not made of dumb materials that meekly allow themselves to be handled; rather, they need to be activated because they can indeed answer: they respond to the subject's handling in accordance with their own laws. And each answer, or each silent pause, provides information that the research project can use.

The questions, naturally, relate not to other realities external to the materials themselves, but to the hands-on relationship that is built up with them. How should I handle you? How can I coax you to answer? What's the secret to generating a flow of communication? How can I make you talk to me? Generating a flow of communication, starting up a transforming dialogue to both, translates in this case to moving ahead with a research project.

So, research goes far beyond an objective analysis, a rational forecast of results, the more or less routine application of a series of pre-tested working procedures. Actually, it reveals itself as a period of intensity, of full vitality in a relationship of the subject with the world around her that goes far beyond a calculation of end goals: 
There is information based on the experience of Love that is valid precisely because it is not distorted by an obsessive pursuit of (pseudo-) objectivity and is based not on participant observation, but on a shared experience (Devereux, 1967, p. 118).

It is mere ignorance that leads then to the supposition that connection of art and esthetic perception with experience signifies a lowering of their significance and dignity. Experience in the degree in which it is experience is heightened vitality. Instead of signifying being shut up within one's own pribate feelings and sensations, it signifies complete interpenetration of the self and the world of objects and events (Dewey, 1934, p. 19).

\section{Truth, or: artistic practice as a subversion of discourses}

Love is blind: the proverb is false. Love opens his eyes wide, love produces clear-sightedness: 'I have, about you, of you, absolute knowledge.' [...] Always the same reversal: what the world takes for 'objective,' I regard as factitious; and what the world regards as madness, illusion, error, I take for truth (Barthes, 1977, p. 229-230).

At this moment, there arises the absolute originality of the research project, the moment when the consideration of the object of research is radically different from how others view it or what common sense would dictate. Therein lies research's potential to transform the world, to revolutionize conventional wisdom. But accomplishing this requires in many cases a moment of insecurity and loss of recognizable landmarks (see Barthes' chapter, not discussed here, I Am Crazy) (1977, p. 120-121), when the researcher hesitates between following common sense and trusting her own clear-sightedness. It's a very fragile moment, when curiosity may be squeezed out under the weight of convention - both that of commonly-held beliefs, and conventions about research with regard to methods of working, systemic arrangement of procedures and sharing the study processes with others. Moreover, this applies not only to the respective areas of knowledge in which the research project is set (history, sociology, daily living), but also to the very functioning of the environment in which the research project is taking place: the study programme. This obliges one in many cases to flout, subvert or alter rules. Commonly used criteria and ways of operating (ways of assessing processes, protocols for sharing the research with others, 
ways of co-working) are accordingly called into question by the very research projects that they apply to.

The researcher should make a real effort to offload the pesky burden of explicative science, or of abusively-rationalizing 'common sense', that likes to daub any event that suddenly grabs our attention with the drab greyness of custom to 'protect' us from a hard-to-handle world. The scientist's role is precisely that of handling the world, getting to grips with it; his basic faculty will be to 'apply curiosity' to the innumerable holes in the explicative fabric, which are so commonplace that it takes a considerable effort to make them show up (Moles, 1957, p. 176). 


\section{Notes}

${ }^{1}$ Of course, in order to facilitate this perspective that focuses on subjectivity, it is necessary to abstract other fundamental dimensions of research, such as its collective and relational character. I have tackled the collective and collaborative dimension of research in other articles. See Pérez Royo (2012) and Pérez Royo and Monni (2015).

${ }^{2}$ Once we've managed to reorganize, or at least question, the functioning that we've taken as valid in research into the arts, it would be interesting to extrapolate that research to other related knowledge fields such as the humanities, which at present follow the academic criteria of the positive sciences, applying them to their specific procedures with some measure of difficulty. I agree with Dieter Lesage's avowal that this is the big opportunity of the debate about research into the arts (Lesage, 2012).

${ }^{3}$ While other aspects of research, such as methodology and the creation of tools, have received exponentially growing attention in recent years, the ethical dimension of research has been sidelined to private conversations on the fringes of the basic activities that most master's degree programmes take it upon themselves to organize, such as seminars, reading circles, think tanks etc.

${ }^{4}$ Love's potential for change has not been overlooked in other areas: it has proved to be a very interesting term not only to look at the subversive potential of artistic research, but also to challenge current political thinking. Proof of this is attention paid to this concept in the last years. Hardt and Negri resort to love in the last chapter of Multitude, in which it is defined as "[...] a deployment of force that defends the historical progression of emancipation and liberation" (Hardt; Negri, 2004, p. 351). Badiou, even though from a different perspective, also seems to firmly believe in love's power of positively subverting our current values (Badiou, 2009). Many other authors (for example, Beardsworth, 2006; Verwoert, 2009) have also worked in a similar direction, liberating the concept of love from its bourgeois understanding (linked to terms such as possession and privacy, restricted to the narrow area of the family) and retrieving a more ample conception of it.

${ }^{5}$ In this text I've chosen, in many cases, to use terms (researching subject and object of the research) that have no bearing at all on the reciprocal relationships that I defend in the content; my purpose is to force the language, in such a way that one can think of an object as having the characteristics of a subject and vice-versa. Moreover, I use the terms researcher, creator and artist interchangeably.

\section{References}

BADIOU, Allain; TRUONG, Nicolas. In Praise of Love. London: Profile Books, 2012 [2009].

BARTHES, Roland. A Lover's Discourse: fragments. New York: Hill and Wang, 2001 [1977].

BEARDSWORTH, Richard. A Note to a Political Understanding of Love in our Global Age. Contretemps: an online journal of philosophy, Sydney, University of Sydney, n. 6, p. 2-10, Jan. 2006. 
DELEUZE, Gilles. Negotiations. New York: Columbia University Press, 1995 [1990].

DEVEREUX, Georges. From Anxiety to Method in the Behavioral Sciences. The Hague/Paris: Mouton \& Co., 1967.

DEWEY, John. Art as Experience. New York: Perigee Books, 1980 [1934].

HARDT, Michael; NEGRI, Toni. Multitude: war and democracy in the age of empire. New York: The Penguin Press, 2004.

LE ROY, Xavier. Product of Circumstances. 1999. 1 performance.

LESAGE, Dieter. Who's Afraid of Artistic Research?: on measuring artistic research output. In: LESAGE, Dieter; BUSCH, Kathrin (Ed.). A Portrait of the Artist as a Researcher. Antwerp: The Academy and the Bologna Process/MuHKA, 2009. P. 84-93.

LÉVI-STRAUSS, Claude. The Savage Mind. London: Weidenfeld and Nicolson, 1966 [1962].

MOLES, Abraham. La Creación Científica. Madrid: Taurus, 1986 [1934].

PÉREZ ROYO, Victoria. Knowledge and Collective Practice. In: BRANDSTETTER, Gabriele; KLEIN, Gabriele (Ed.). Dance [and] Theory. Bielefeld: Transcript, 2012. P. 51-62.

PÉREZ ROYO, Victoria; MONNI, Kirsi. Composition: relatedness and collective learning environments. In: ALLSOPP, Ric; MONNI, Kirsi (Ed.). Practicing Composition: making practice - texts, dialogues and documents 2011-2013. Helsinki: Theatre Academy, University of the Arts Helsinki/Kinesis 6, 2015. P. 89-135.

WERVOERT, Jan. Masters and Servants of Love. Gas, Copenhagen, CA Andersson/The Danish Arts Council, n. 4, p. 8-17, 2009.

Victoria Pérez Royo is assistant professor of Aesthetics at the University of Zaragoza, co-director of the Master of Arts in Performing Arts Practice and Visual Culture (Universidad de Castilla-La Mancha \& Reina Sofía Museum, Madrid), guest professor at international programs of artistic research in Europe. She is member of Artea (www.arte-a.org), where she coordinated various projects. She is editor, together with José A. Sánchez, of the book Practice and Research (2010).

E-mail: vicpr@unizar.es

This unpublished text, translated by Deborah Lockett and proofread by Ananyr Porto Fajardo, is also published in Portuguese in this issue.

Received on December $15^{\text {th }}, 2014$

Accepted on May $8^{\text {th }}, 2015$ 